\title{
Assessment of Forest Fire Rating Systems in Typical Mediterranean Forest, Crete, Greece.
}

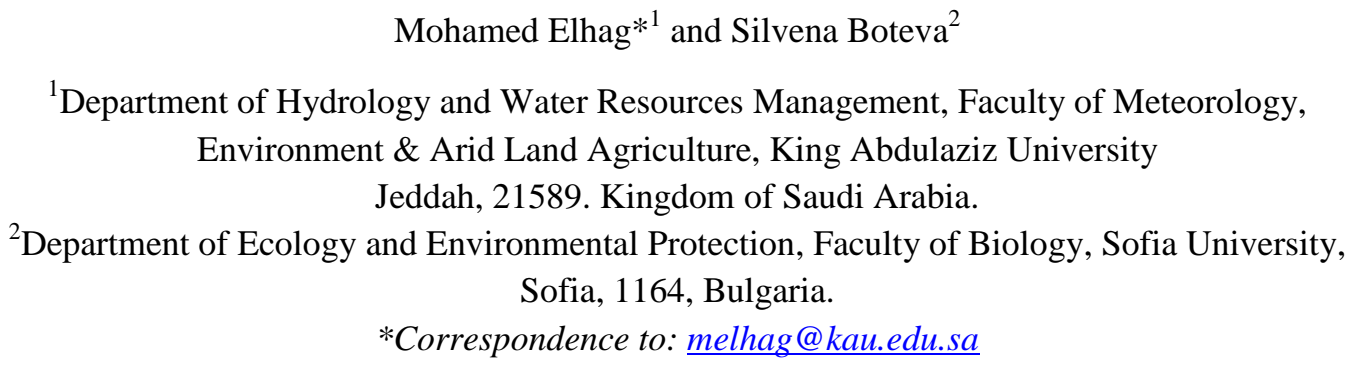

\section{Abstract}

The Fire Weather Index (FWI) module was tested under the Mediterranean- type conditions of Crete (Greece) for the two fire seasons 2008-2009. High correlations were found between the Fine Fuel Moisture Code (FFMC) and the Duff Moisture Code (DMC. The Drought Code (DC) was insignificantly correlated with the soil moisture content. No significant correlation was found between the area burned by wildfires and any component of the FWI system during the studied period, unlike fire occurrence with which most of the components were highly correlated. Meanwhile, the Keetch-Byram Drought Index (KBDI) of the American Forest Fire Danger Rating System (NFFDRS) was also examined under the same conditions. It provided a useful means of monitoring general wetting and drying cycles, but is inadequate for indicating daily fire danger throughout the fire season in our region. Weak correlations between the KBDIthe fire occurrence and the area burned were found for the two fire seasons studied-2008-2009. Correlations between the KBDI and litter, duff and soil did not give statistically sound results. On the contrary, the KBDI seemed to predict with high accuracy the moisture content of three annual plants (Piplatherum miliaceum, Parietaria diffusa, Avena sterillis) with a shallow rooting system of Pinus halepensis forest understory in the region. This indicated that the index was adequate, to a certain extent, to represent the upper soil layers' water status, while it is unsuitable to predict needles moisture content of Pinus halepensis, which has a deep rooting system.

Keywords: Danger Rating Systems, Data Analysis, Forecasting, Forest Fires, Fires Risk, Moisture Content. 


\section{Introduction}

Fire presents a main disturbance to natural ecosystems in the Mediterranean regions, leading to considerable ecological and economic losses. Thus, there is a great benefit can be obtained throughout anticipation. Therefore, the likelihood of fire incidence on a given date and its expected severity can be anticipated in advance. Fire danger rating is the expression of both variables and constants environmental factors that influence the occurrence, behavior, suppression efforts and detrimental effects of wildland fires in a certain area (Amatulli et al. 2013).

The incidence and the spread of forest fires be contingent on several environmental and anthropogenic factors. Even in regions like the Mediterranean region where most fires are iniciated by humans, natural circumstances that affect the fuel properties play a very significant role in the number of fires and the burned area (Bajocco et al. 2015).

Monitoring of live and dead fuel moisture can be used as an indicator of forest fire danger, if combined with simultaneous measurements of meteorological parameters. Forest fire danger rating systems are based on the integration of meteorological parameters with bio-physical characteristics of the fuels to forecast their combustibility and flammability, combined with the risk posed by human activities and natural phenomena (Pereira et al. 2011)

During the past six decades, much research has been accomplished and incorporated within several fire danger systems. These systems have evolved from several regional versions into the single National System of today. The Canadian Forest Fire Danger Rating System (CFFDRS), referred to prior to 1976 as the Canadian Forest Fire Behavior (or Behavior Rating) system, which embraces all aspects to evaluate fire danger and the forecast of fire behavior, including the 
Nat. Hazards Earth Syst. Sci. Discuss., https://doi.org/10.5194/nhess-2017-318

Manuscript under review for journal Nat. Hazards Earth Syst. Sci.

Discussion started: 9 October 2017

(c) Author(s) 2017. CC BY 4.0 License.

Fire Weather Index (FWI) System and Fire Behavior Prediction (FBP) System. (Pasqualini et al.

54

55

56 2011).

The CFFDRS has been under development in its present form since 1968, when the Canadian Forestry Service (CFS) adopted a modular approach to a new National System of fire danger rating. The first major module or sub-system of the CFFDRS, the (FWI) provides numerical rating of relative wildland fire potential in a standard fuel type on level terrain (Dexter et al. 2013). The second major subsystem of the CFFDRS was conceived on the original modular approach, as a series of regionally developed guides to fire behavior characteristics for specific fuel complexes. These "Burning Indexes" or fire "behavior indexes" have become known as the Canadian Forest Fire Behavior Prediction (FBP) System, Together with the (FWI) form the National System of Fire Danger Rating System in Canada (Pasqualini et al. 2011).

While FWI was originally developed for use in Canadian pine forests (de Jong et al. 2016), it was also extensively used in different environments and in other countries like France, Indonesia, Malaysia, Mexico, New Zealand, Portugal, Spain, and the USA (Wang et al. 2017). It was applied both for establishing new relationships between the FWI System components and the fuel moisture/fire behaviour observed in local fuels and for distinguishing periods of high fire activity. FWI index has also been found to outperform or at least match the performance of other fire danger rating systems regarding highlighting periods with high fire activity in non-native environments (de Jong et al. 2016). Furthermore, computer systems for fire management have been used in Canada since the early 1970s. Later, in 1992, the Canadian Forest Services investigated the application of geographic information systems for constructing the fire management information systems and developed the spatial fire management system (Lawson \& Armitage 2008). In the 1980s and 1990s, these remote automatic weather stations and 
Nat. Hazards Earth Syst. Sci. Discuss., https://doi.org/10.5194/nhess-2017-318

Manuscript under review for journal Nat. Hazards Earth Syst. Sci.

Discussion started: 9 October 2017

(c) Author(s) 2017. CC BY 4.0 License.

respectively the associated communications technology allowed the collection of weather data from isolated locations in almost real time on a local and even a national level (Taylor and Alexander 2006). The CFFDRS is also used in the framework of Copernicus European Forest Fire Information System (EFFIS) system which supports the services responsible for forests protection against fires in the EU countries and providing current information on fires to the European Commission services and the European Parliament.

82 In reviewing early fire danger research in Canada, two perceptions are worth to consider. First the development process which was kept from system to system. Second, there was a simplicity trend. Both are necessary for weather measurement and in the method of calculation (Wrathall 1985).

It is well understood that the incidence and behavior of forest fires depend mainly on short-term weather influence of no more than several days duration (Amatulli et al. 2013). Yet, throughout the history of fire danger rating, runs a persistent interest in the effects of weather over a much longer term. Accounting for long-term drying is necessary because it provides guidance to the fire manager during critical conditions. This does not imply that fires cannot occur without prior, long-term moisture deficiency (Dimitrakopoulos \& Bemmerzouk 2003); in other terms a drought condition is not a prerequisite for the occurrence and spread of fire in any area (Amatulli et al. 2013).

The Keetch-Byram Drought Index (KBDI) was first introduced. It was defined as a number representing the net effect of evapotranspiration and precipitation in producing cumulative moisture deficiency in deep duff or upper soil layers. The material may be soil humus. It may

97 also be organic material that consists of buried wood, such as roots in varying degree of decay, at 
Nat. Hazards Earth Syst. Sci. Discuss., https://doi.org/10.5194/nhess-2017-318

Manuscript under review for journal Nat. Hazards Earth Syst. Sci.

Discussion started: 9 October 2017

(C) Author(s) 2017. CC BY 4.0 License.
Natural Hazards and Earth System

Sciences

Discussions
98

99

100

101

102

103

104

105

106

107

108

109

110

different depths below the mineral soil surface. The KBDI is a daily index that ranges from 0 to 800, where higher values are associated with drought. The index is calculated from daily observations of precipitation amount and maximum air temperature (Keetch \& Byram 1968). Conceptually, the index expresses, in hundredths of an inch, the moisture deficiency in soil, after accounting for density of vegetation coyer, precipitation, and evapotranspiration losses. KBDI is easy to compute and provides a continuous record because it is updated daily. It is good for certain localities typical of fire sites as the index relies on point-source data. Since 1990, the KBDI has been in use at selected Mediterranean locations of Greece (Dimitrakopoulos \& Bemmerzouk 2003). Also, Dolling et al. (2005) reported a strong link between the KBDI and total acres burned for the Hawaiian Islands. KBDI is one of the several indicators that fire managers use to track fire potential in Hawaii as it is used also by the Florida Division of Forestry for classifying fire-season severity and is applied by fire managers in Texas to monitor fire potential and effect burn bans (Dolling et al. 2009).

The objective of this study is to test and evaluate the following FFDRS, to propose possible modifications that would better adapt these systems to the Mediterranean conditions. The implemented forest fire danger rating systems are the Canadian Forest Fire Danger Rating System (CFFDRS), and Keetch-Byram Drought Index (KBDI) of the American National Forest Fire Danger Rating System (NFFDRS).

\section{Materials and Method}

\subsection{General description of the studied area}

Akrotiri region is situated $6 \mathrm{~km}$ East of Chania (Crete, Greece), at an altitude of $185 \mathrm{~m}$ a.s.l., at approximately $35^{\circ} 31^{\prime} \mathrm{N}$ and $24^{\circ} 03^{\prime} \mathrm{E}$. The mean annual rainfall is about $600 \mathrm{~mm}$, December, 
Nat. Hazards Earth Syst. Sci. Discuss., https://doi.org/10.5194/nhess-2017-318

Manuscript under review for journal Nat. Hazards Earth Syst. Sci.

Discussion started: 9 October 2017

(c) Author(s) 2017. CC BY 4.0 License.

January and February being the period of the higher precipitations (Elhag \& Bahrawi 2016). The ecosystem investigated is a typical Mediterranean forest presented by Pinus halepensis with 50\% crown closure. The stand is southwest exposed with a slope of $20 \%$. The experiment was settled for two consecutive fire seasons in 2008 and 2009. Daily measurements were conducted at 14.00h. Samples were taken from soil, litter, duff and under the canopy of the forest. They were transported after sampling in hermetically sealed aluminum containers, for preventing evaporation. For each parameter, three samples were collected. The daily moisture value is the average of the three values. The daily weather data (air temperature, air relative humidity, $10 \mathrm{~m}$ wind speed, and $24 \mathrm{~h}$ accumulated precipitation) for calculating the (FWI) indexes were obtained from the Akrotiri Airport meteorological station, located about $5 \mathrm{~km}$ from the site where the experimental site was established (Fig. 1).

\subsection{Canadian Forest Fire Danger Rating System}

The system is dependent only on weather and does not consider differences in risk, fuel, or topography. It provides a uniform method of rating fire danger across Canada. The six components are described below:

\subsubsection{Fine Fuel Moisture Code (FFMC)}

This code is an indicator of the relative ease of ignition and flammability of fine fuel. In order to permit conversion of moisture content into a code, a scale, called the FF scale, was defined based on the following assumptions and equations:

$F=\frac{59.5(250-m)}{147.2+m}$

Eq.1 
Nat. Hazards Earth Syst. Sci. Discuss., https://doi.org/10.5194/nhess-2017-318

Manuscript under review for journal Nat. Hazards Earth Syst. Sci.

Discussion started: 9 October 2017

(c) Author(s) 2017. CC BY 4.0 License.

140 Where $\mathrm{F}$ is the FFMC and $\mathrm{m}$ is the minimum moisture content (which was set equal to $2 \%$ in the

141 scale of the old FFMC: the "Tracer Index") of litter and other cured fuels.

142

\subsubsection{Duff Moisture Code (DMC)}

It was developed after (Van Wagner 1970), field work, mainly in Pinus resinosa and Pinus banksiana stands. The method was based on transferring rectangles of organic matter to trays of $60 \times 40 \mathrm{~cm}$ in an area set in forest floor, and to weigh daily. The type expression is:

$P=c[\log (M \max )-\log (M-E)]$

Eq. 2

Where $\mathrm{c}$ is a scale constant, $\mathrm{P}$ is code value, $\mathrm{M}$ is moisture content, and $\mathrm{E}$ is the equilibrium moisture content. According to the data recorded, $\mathrm{M}$ max was set equal to 300 and $\mathrm{E}$ to 20 .

\subsubsection{Drought Code (DC)}

The Drought Code (DC) was improved by (Murray et al. 2012) and gives information on the soil water rather than on the moisture condition of a given slow-drying forest fuel. Later on, several researchers (Van Wagner 1970, Dimitrakopoulos \& Bemmerzouk 2003) found that such an index was quite suitable to represent certain fuels, since, like the soil layer, it loses moisture exponentially. As an exponential expression of the moisture equivalent $\mathrm{Q}$, the chosen scale equation is:

$D=400 \ln (800 / Q)$

Eq. 3

Where, D is the current DC. The constant 400 represents the maximum theoretical moisture content that can be held by the fuel represented by the DC.

\subsubsection{Initial Spread Index (ISl)}


Nat. Hazards Earth Syst. Sci. Discuss., https://doi.org/10.5194/nhess-2017-318

Manuscript under review for journal Nat. Hazards Earth Syst. Sci.

Discussion started: 9 October 2017

(C) Author(s) 2017. CC BY 4.0 License.

(c) (i)

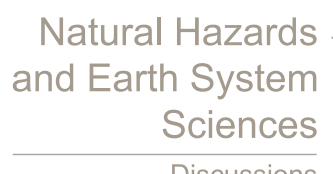

Discussions
160

161

162

163

164

165

166

167

168

169

170

171

172

173

The ISI is merely the product of functions of wind and fine fuel moisture, together with a reference constant 0.0208 . This constant was determined at a later stage, and was designed to make the B-scale FWI equal to 40 for an arbitrary set of conditions. The constant itself was multiplied by 10 to provide a convenient range of numerical values for the ISI. The equation is then formulated as below:

$R=0.208 f(W) f(F)$

Eq. 4

Where, $\mathrm{R}$ is the Initial Spread Index.

\subsubsection{Buildup Index (BUI)}

The BUI is a combination of the DMC and the DC. Since the DC was introduced to the system after the DMC, a method was desired to give a limited, variable weight to the DC, reserving the main effect to the DMC. When the DMC is near zero, the DC should not affect the daily fire danger, no matter how high its level is. When the DMC and the DC are combined, the BUI is given by:

$U=0.8 P D /(P+0.4 D)$

Eq. 5

Where $\mathrm{U}$ is BUI, $\mathrm{P}$ is DMC, and $\mathrm{D}$ is $\mathrm{DC}$.

\subsubsection{Fire Weather Index (FWI)}

The FWI is obtained by using the ISI and BUI values. To give the Fire Weather Index meaning as a measure of fire intensity, factors are required for both rate of spread and fuel consumption.

The ISI clearly represents the rate of spread, but BUI is simply a blend of two fuel moisture codes. The intermediate function required to calculate the FWI is expressed as follows: 
Nat. Hazards Earth Syst. Sci. Discuss., https://doi.org/10.5194/nhess-2017-318

Manuscript under review for journal Nat. Hazards Earth Syst. Sci.

Discussion started: 9 October 2017

(c) Author(s) 2017. CC BY 4.0 License.

(c) (i)

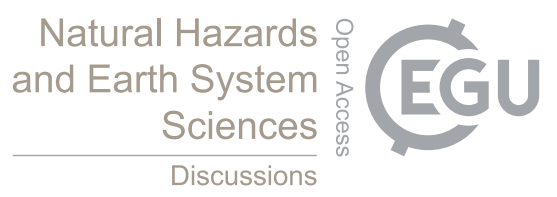

181 Where, $\mathrm{R}$ is the present day's ISI that is adjusted by the factor 0.1 to fit the scale. The following

182 relation can give the final equation:

$\ln S=2.72(0.434 \ln B)^{0.647}$

Eq. 7

184 For general use, the FWI and its various system components are usually rounded to the nearest whole number; any FWI value of less than 0.5 will, thus, be reported as zero.

\subsection{Keetch-Byram Drought Index}

The KBDI is a daily index that ranges from 0 to 800 , where higher values are associated with drought. The index is calculated from daily observations of precipitation amount and maximum air temperature (Keetch \& Byram 1968). Conceptually, the index expresses, in hundredths of an inch, the moisture deficiency in soil, after accounting for density of vegetation coyer, precipitation, and evapotranspiration losses.

If climate elements that affect transpiration, such as temperature, relative humidity, and solar radiation have constant values and is observed a directly proportional rate between the amount of water loss from the duff layer and its amount in the layer, then the conceptual equation can be:

$w=w_{c} \exp (-\tau / t)$

Eq. 8

Where $\mathrm{w}$ is the available water (in inches) in the soil-duff layer for plants, wc is the corresponding field capacity (in inches) of available water in the layer, $\tau$ is the time (in days) when the soil-duff layer loses moisture, and $\mathrm{t}$ is the evapotranspiration timelag (in days) 
Nat. Hazards Earth Syst. Sci. Discuss., https://doi.org/10.5194/nhess-2017-318

Manuscript under review for journal Nat. Hazards Earth Syst. Sci.

Discussion started: 9 October 2017

(c) Author(s) 2017. CC BY 4.0 License.

necessary for the soil-duff layer moisture content values to decrease to $1 / \mathrm{e}$ of its initial value, where $\mathrm{e}$ is the base of natural logarithms).

201

202

203

204

205

206

207

208

209

210

211

212

213

214

215

216
The next step is to establish a relationship among the evapotranspiration timelag $t$, the temperature $\mathrm{T}$ and the mean annual rainfall $\mathrm{R}$. The functional equation can be written as shown:

$1 / t=f_{1}(T) f_{2}(R)$

Eq. 9

In which $f_{1}$ and $f_{2}$ are time functions that can remain undetermined. $\mathrm{t}$ is shown as a function of $\mathrm{R}$ for two different values of $\mathrm{T}$. Since there would be no vegetation for $\mathrm{R}=0$, it might appear that $t \rightarrow \infty$ as $R \rightarrow 0$. Moreover, the moisture deficiency $Q$ will be defined by:

$\log d Q=\log \left(w_{c}-Q\right)+\log f_{1}(T) \log f_{2}(R)+\log d \tau$

Eq. 10

When determining the functions $f_{1}(T)$ and $f_{2}(R)$, it is required the evapotranspiration timelag t to be written with more specific notation - $\mathrm{t}_{\mathrm{TIR}}$.

If one with $\mathrm{T}=\mathrm{T}$ and the other with $\mathrm{T}=\mathrm{T}_{0}$ and with $\mathrm{R}$ having the same value in both equations, then their ratio can be expressed as:

$\left.\frac{t_{T, R}}{t_{T_{0}, R}}\right)=\left[\frac{d w_{T, R}}{d t} / \frac{d w_{T_{0}, R}}{d t}\right]_{t=0}^{-1}$ Eq. 11

3 It is needed to approximate the relationship obtained by equation (9) with an empirical equation which is reasonable and consistent with the involved main physical concepts. Therefore, the approximation of equation (9) leads to the following exponential equation:

$t_{T, R}-t_{T, \infty}=K \exp (-a R)$ 
Nat. Hazards Earth Syst. Sci. Discuss., https://doi.org/10.5194/nhess-2017-318

Manuscript under review for journal Nat. Hazards Earth Syst. Sci.

Discussion started: 9 October 2017

(c) Author(s) 2017. CC BY 4.0 License.

217 In which a is a constant and $\mathrm{K}$ is a function of $\mathrm{T}$ only. However, when $\mathrm{R}=0$, then $t_{T, 0}-t_{T_{i} \infty}$

218 and therefore $\mathrm{K}=t_{T, 0}-t_{T_{i} \infty}$

219 Where, $\mathrm{t}$ as written with the appropriate subscripts for the specific notation form. When

220 comparing this equation with equation (9) it shows that $f_{2}(\mathrm{R})$ can be considered as the quantity:

222 In the range from $\mathrm{T}=50^{\circ} \mathrm{F}$ to $\mathrm{T}=110^{\circ} \mathrm{F}$, the empirical equation can closely approximate the

223 potential evapotranspiration rate curve:

224

$-\left[\frac{d w_{T_{i}, 50}}{d t}\right]_{t=0}=0.352 \exp (0.0486 \mathrm{~T})-3.015$

Eq. 14

225 Since the potential evapotranspiration ratio in the right part of this equation will be unchanged

226 for all values of R; it can be expressed with regard to equation (14). If we set the reference

227 temperature $\left(\mathrm{T}_{0}\right)$ at $80^{\circ} \mathrm{F}$, equation (14) will have a numerical value for the potential

228 evapotranspiration rate amounting to 14.18 hundredths of an inch per day.

229

When $\mathrm{T}=\mathrm{T}_{0}=80^{\circ} \mathrm{F}$ (arbitrarily chosen as the reference temperature) and $\mathrm{wc}=800$ hundredths

230 of an inch of water, then, from the above equation, $\mathrm{t}_{80,50}=56.41$ days. Hence, from equation

231 (24), it follows that $t_{80, \infty}=25.64$ days. Expressing the terms of evaluated numerical constants with only dQ in the left member gives the final equation:

233

$d Q=\frac{[800-Q][0.968 \exp (0.0486 T)-8.3] d t}{1+10.88 \exp (-0.0441 R)} * 10^{3}$

Eq. 15 
Nat. Hazards Earth Syst. Sci. Discuss., https://doi.org/10.5194/nhess-2017-318

Manuscript under review for journal Nat. Hazards Earth Syst. Sci.

Discussion started: 9 October 2017

(c) Author(s) 2017. CC BY 4.0 License.

234 The drought factor $\mathrm{dQ}$, is conveniently computing daily in which case the time increment dt is 235 placed equal to 1 day. The final Spread Index unit equation can be written in the following 236 equation mentioned by Leverkus et al. (2014):

In the derivation of the basic equations, the fuel layer has been included with the soil. In the

239 setting of wc at 8 inches of water, it is assumed that the wc refers both to the soil and the fuel 240 layer.

\section{Results and Discussion}

\subsection{CFFDRS}

The burned area is the most obvious characteristics of a fire used in statistics. It can be dependent on a number of factors mainly the occurrence of simultaneous fires, policies and priorities in controlling fires, differences in fire accessibility, organization efficiency of the fire control, composition and amount of fuel, weather conditions and topography.

\subsubsection{Burned Area, Number of Fires and the Components of the (FWI).}

The variables tested as predictors of area burned and number of fires are the three moisture codes FFMC, DMC, and DC, the two intermediate indices, ISI and BUI, and the FWI. The correlation matrix of these variables shows highly significant correlations between fire occurrence and DMC $(r=0.89)$, DC $(r=0.78)$, BUI $(r=0.90)$, and FWI $(r=0.60)$. Despite these results, there is no significant correlation between any component of the (FWI) system and burned area. A step-wise multiple linear regression analysis was also performed but results indicated that the components 
Nat. Hazards Earth Syst. Sci. Discuss., https://doi.org/10.5194/nhess-2017-318

Manuscript under review for journal Nat. Hazards Earth Syst. Sci.

Discussion started: 9 October 2017

(c) Author(s) 2017. CC BY 4.0 License.

of the FWI explained an insignificant part of the variance in the burned area (Fernandes et al. 2014)

\subsubsection{Fine Fuel Moisture Code (FFMC).}

257 The potential range of the FFMC is from 0 to 101. In the given case, FFMC values range from 25810.3 up to 96.5 , with a mean value of 84.95 for the two investigated fire seasons. In this case

259

260 $90 \%$ of the computed values are above 75 , as 65 is the threshold value at which the likelihood of fire ignition increases exponentially (Jimenez-Gonzalez et al. 2016). These observations suggest that most of the days during the season are appropriate for fire occurence (Levin et al. 2016).

\subsubsection{Duff Moisture Code (DMC).}

The DMC has a virtually unlimited range. This implies that, given suitable fuel beds, the most of the days during the fire season will have a potential for extreme fire behavior (Parr et al. 2007).

\subsubsection{Drought Code (DC).}

The DC responds slowly to environmental changes (Van Wagner 1970). In the spring, its initial value depends upon the intensity of the previous fall and winter rains. The observation of the DC values shows that the early spring value is close to 0 , rising as the season progresses to values which exceed 1360 in the early fall (the largest DC value of the two fire seasons was 1367, recorded in October 2008). The average monthly rate of the DC shows an accelerating increase in the early and late spring, and a slower increase during summer and a progressive decrease in the early fall, after the first rains (Andrew et al. 2016).

\subsubsection{Initial Spread Index (ISI).}


Nat. Hazards Earth Syst. Sci. Discuss., https://doi.org/10.5194/nhess-2017-318

Manuscript under review for journal Nat. Hazards Earth Syst. Sci.

Discussion started: 9 October 2017

(c) Author(s) 2017. CC BY 4.0 License.

Mean ISI values are generally small and relatively invariable in time. A combination of drying weather and strong winds in late spring creates a maximum which then diminishes off to about $1 / 3$ of its value by October. The highest mean and maximum values occur in June and July, with the summer period also encountering also the maximum values with a mean of 14.65.

\subsubsection{The Fire Weather Index FWI.}

The FWI combines the values obtained from ISI and BUI (Ganteaume et al. 2013). The duration of the fire season is variable from one year to the other are showed in Table 1. For the two fire seasons, May represents the threshold month where FWI values are classified in the "High" and "Extreme" classes in most days, thus indicating the actual start of the fire season. When comparing the two studied fire seasons, the one in 2009 was much longer (May-November) than that of 2008, when the fire season was restricted to May-September. This is due to the difference in the amount of fall precipitation (120.6 $\mathrm{mm}$ for 2008 against $25.0 \mathrm{~mm}$ for 2009), which is reflected in the FWI values. Consequently, it can be reported that the FWI can be successfully used to indicate the beginning, the peak and the end of the fire season in the Mediterranean-type ecosystem of Greece (Petropoulos et al. 2010, Turco et al. 2016).

The observation of the fire danger classes shows that the summer period (June- August) accounts for about $95 \%$ of the "Extreme" values recorded during the whole fire season, thus indicating the height of period with fires (Arpaci et al. 2013). May and September also experiences a big percentage of FWI values in the "High" and "Extreme" classes. The analyses of the number of fires in relation to FWI classes (Tab. 1) indicate clearly that more than $80 \%$ of fires occur during days within the "Extreme" FWI class. 
Nat. Hazards Earth Syst. Sci. Discuss., https://doi.org/10.5194/nhess-2017-318

Manuscript under review for journal Nat. Hazards Earth Syst. Sci.

Discussion started: 9 October 2017

(c) Author(s) 2017. CC BY 4.0 License.

The statistics parameter indicates that measured (observed) and the predicted values of fine fuel moisture are highly correlated. When conducting a t-test for both measured and predicted values of litter moisture content it indicated that there was no significant difference at $95 \%$ confidence level. Daily variations of moisture content of predicted and observed fine fuel is shown in Figure

The two sets of points have similar trend during the investigated seasons. It is observed a better correlation during the summer season, when it is not raining. This proves the model sensitivity to daily changes in climate elements, namely temperature, relative humidity, and wind speed. In occasions instantly after rain, this model under-predicts the moisture content slightly, but after that resumes in a short time. Correlation between measured and predicted values (at 95\% confidence level) gave an $r=0.89$.

\subsubsection{Duff Moisture Content.}

Even if a correlation at $95 \%$ level confidence between the measured and the predicted duff values of moisture content gives an $r=0.75$, the model predicts higher values for all descriptive statistical parameters. Moreover, a t-test of paired predicted and observed values for duff moisture content indicated significant difference at $95 \%$ confidence level.

The visual observation of comparison chart of predicted and observed duff moisture values (Fig. 3) shows that the two sets of points seems to behave differently. In the higher range of moisture content, the predicted values present a delay in time before they start responding to rain occurrence. This may be due to the torrential nature of precipitation in the Mediterranean region, and/or to the discontinuous canopy closure characteristic of the Mediterranean pine forest type, which differs from the Canadian conditions (Parr et al. 2007). 
Nat. Hazards Earth Syst. Sci. Discuss., https://doi.org/10.5194/nhess-2017-318

Manuscript under review for journal Nat. Hazards Earth Syst. Sci.

Discussion started: 9 October 2017

(c) Author(s) 2017. CC BY 4.0 License.

In addition, the duff layer is certainly notably less important in the Mediterranean conditions, regarding quantity and depth, than that of the typical Canadian environment. In the lower scale, the model seems to be limited in its predictions, as soon as the observed duff moisture content values decrease fewer than $20 \%$. This can be explained by the fact that the DMC was set with an equilibrium moisture content of $20 \%$. This means that the lowest scale predicted by the model should be at least equal to 20 . Unlike, during the summer season the duff moisture content, in our ecosystem, is in most cases below the threshold of the model predictions.

\subsection{KBDI}

\subsubsection{Evaluation of the KBDI Trends with Time.}

The study shows a very high drought index, the mean value \pm standard deviation was $660 \pm$ 182.9 for the period March 2008 - November 2009 (640 days). In $66.1 \%$ of the days the drought index exceeds the value 650 constituting the "Extreme drought" class. An annual trend can be discernible, though the effects of year-to-year differences are non-negligible and the period studied is certainly short. Following the end of the rainy period, usually at the beginning of spring, there is a continuous increase in the drought index value, reaching quickly the maximum value by mid of May. The precipitations occurring during the fall period with their small amount and discontinuous feature seem to be insufficient to reduce significantly the drought index.

Consequently, the "Extreme" drought persists until the beginning of the winter time, where relatively important and continuous precipitation occurrences combined with low temperature drop the index value to the "High" and "Moderate" class. It is worth noting that the drought index never restored the "Very Low" and "Low" classes. This is probably due to the exceptionally drought weather that occurred during the year 2009. 
Nat. Hazards Earth Syst. Sci. Discuss., https://doi.org/10.5194/nhess-2017-318

Manuscript under review for journal Nat. Hazards Earth Syst. Sci.

Discussion started: 9 October 2017

(c) Author(s) 2017. CC BY 4.0 License.

The KBDI seems to over predict in time the end of the fire season. This emphasizes the fact that long-term moisture deficiency cannot be used to forecast critical fire situations, because fires are caused from a combination of factors that occur in conjunction with drought conditions. Consequently, it is not possible to establish precise "threshold value" at which critical fire situations may or may not develop (Dimitrakopoulos \& Bemmerzouk 2003).

\subsubsection{The Keetch-Byram Drought Index as a predictor of foliage moisture content.}

Linear and exponential equations were tested for four species (Avena sterilis, Parietaria diffusa, Piplatherum miliaceum and Pinus halepensis) to see which equation best fits the relationship of plant moisture content and the KBDI (Tab. 2).

All species were linearly better correlated to the KBDl. Piplatherum miliaceum showed a strong linear decay with increasing KBDI (meaning that the higher the KBDI and thus the more severe the drought, the lower the plant moisture content); so, did Avena sterrilis, Parietaria diffusa, while Pinus halepensis revealed a positive weak correlation.

Most the fluctuations in plant moisture content are accounted for by the KBDI for the species monitored: Piplatherum miliaceum (Fig. 4) (variance explained 88\%), Parietaria diffusa (Fig. 5) (68\%), and Avena sterillis (Fig. 6) (72\%). For Pinus halepensis, the variance explained was very low (4\%). The T test was performed for the three-herbaceous species showing strong correlation with the KBDI whose results indicated that the observed and the predicted (from the KBDI) moisture content values are not significantly different at the $95 \%$ confidence level. On the other hand, and according to Clavero et al. (2011), predictions of herbaceous plant and shrubs moisture content within $20 \%$ are scientifically sound and adequate for prescribed fire planning (Brown et al. 2015). 
Nat. Hazards Earth Syst. Sci. Discuss., https://doi.org/10.5194/nhess-2017-318

Manuscript under review for journal Nat. Hazards Earth Syst. Sci.

Discussion started: 9 October 2017

(c) Author(s) 2017. CC BY 4.0 License.

\section{Conclusions}

In the first part, the (FWI) system was tested against real data covering two fire seasons and can be applicable as a method for meteorological fire risk assessment for the country. The FWI supports to indicate the duration of the fire season, which is variable from one year to the other. This highly risky period is generally confined between May and the end of September in Chania region. The FWI indicates, also, with a relatively high accuracy the beginning, the peak, and the end of the fire season. The analysis of the number of fires in its relation to FWI classes, for the two fire seasons analyzed, revealed that about 95\% of fires occur during "High" and "Extreme" days. Highly significant correlations were found between "number of fires" and Duff Moisture Content $(r=0.89)$, Drought Code $(r=0.78)$, Buildup Index $(r=0.90)$, and the Fire Weather Index $(\mathrm{r}=0.60)$. On the contrary, no significant correlation was found between the "burned area" and any component of the (FWI). According to Alcañiz et al. (2016), this is not necessarily a reflection on the accuracy and usefulness of the Fire Weather Indices. The analysis of longer time series for further stations with similar environmental conditions to the one investigated would bring more certainty about this specific point. In the second part, the KBDI was tested, and showed to provide a useful means of monitoring general wetting and drying cycles, but was inadequate for indicating daily fire danger throughout the fire season in Chania region. Weak correlations between the KBDI and fire occurrence $(r=0.24)$ and the area burned $(r=0.03)$ were found for the two fire seasons studied-2008-2009. This may be due to several reasons. The KBDI supports to predict with high accuracy the moisture content of three annual plants (Piplatherum miliaceum, Parietaria diffusa, Avena sterillis) with shallow rooting system representing the understory of Pinus halepensis in Chania region. Separate models are developed for determining their moisture content. This indicates that the index is adequate, to a certain extent, to represent 
Nat. Hazards Earth Syst. Sci. Discuss., https://doi.org/10.5194/nhess-2017-318

Manuscript under review for journal Nat. Hazards Earth Syst. Sci.

Discussion started: 9 October 2017

(c) Author(s) 2017. CC BY 4.0 License.

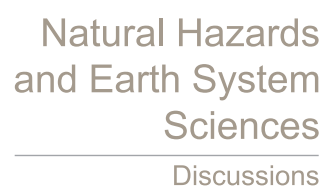

(c) (1)

384

385

386

387

388

389

390

391

392

393

394

395

396

397

the upper soil layers' water status, while it shows to be inapt to predict the needles moisture content of Pinus halepensis, which has a deep rooting system. The KBDI proved to be a satisfactory way of monitoring general wetting and drying cycles, and thus warning fire managers in the early stages about exceptionally wet and dry years. Furthermore, it is believed that monitoring foliage moisture content of the main species in the Mediterranean region as regard to their abundance and dominance and their involvement in most fires, and determining the relationships with the KBDI. By applying the additional data received from KBDI, the EFFIS system could use them for more accurate early fire warning and fire management planning such as prescribed burning when conditions are convenient for it.

\section{Acknowledgment}

This article was funded by the Deanship of Scientific Research (DSR) at King Abdulaziz University, Jeddah. The authors, therefore, acknowledged with thanks DSR for technical and financial support.

\section{References}

Alcañiz M, Outeiro L, Francos M, Farguell J, Úbeda X (2016). Long-term dynamics of soil chemical properties after a prescribed fire in a Mediterranean forest (Montgrí Massif, Catalonia, Spain). Science of The Total Environment 572: 1329-1335.

Amatulli G, Camia A, San-Miguel-Ayanz J (2013). Estimating future burned areas under changing climate in the EU-Mediterranean countries. Science of The Total Environment 450-451: 209-222. 
Nat. Hazards Earth Syst. Sci. Discuss., https://doi.org/10.5194/nhess-2017-318

Manuscript under review for journal Nat. Hazards Earth Syst. Sci.

Discussion started: 9 October 2017

(c) Author(s) 2017. CC BY 4.0 License.

Andrew ME, Ruthrof KX, Matusick G, Hardy GE (2016). Spatial Configuration of Drought Disturbance and Forest Gap Creation across Environmental Gradients. PLoS One 11: $\mathrm{e} 0157154$.

Arpaci A, Eastaugh CS, Vacik H (2013). Selecting the best performing fire weather indices for Austrian ecoregions. Theoretical and Applied Climatology 114: 393-406.

Bajocco S, Dragoz E, Gitas I, Smiraglia D, Salvati L, Ricotta C (2015). Mapping forest fuels through vegetation phenology: the role of coarse-resolution satellite time-series. PLoS One 10: e0119811.

Brown LE, Palmer SM, Johnston K, Holden J (2015). Vegetation management with fire modifies peatland soil thermal regime. Journal of Environmental Management 154: 166-176.

Clavero M, Brotons L, Herrando S (2011). Bird community specialization, bird conservation and disturbance: the role of wildfires. Journal of Animal Ecology 80: 128-136.

de Jong MC, Wooster MJ, Kitchen K, Manley C, Gazzard R, McCall FF (2016). Calibration and evaluation of the Canadian Forest Fire Weather Index (FWI) System for improved wildland fire danger rating in the United Kingdom. Natural Hazards and Earth System Sciences 16: 1217-1237.

Dexter N, Hudson M, James S, Macgregor C, Lindenmayer DB (2013). Unintended consequences of invasive predator control in an Australian forest: overabundant wallabies and vegetation change. PLoS One 8: e69087.

Dimitrakopoulos AP, Bemmerzouk AM (2003). Predicting live herbaceous moisture content from a seasonal drought index. International Journal of Biometeorology 47: 73-79.

Dolling K, Chu P-S, Fujioka F (2009). Natural variability of the Keetch-Byram Drought Index in the Hawaiian Islands. International Journal of Wildland Fire 18: 459-475. 
Nat. Hazards Earth Syst. Sci. Discuss., https://doi.org/10.5194/nhess-2017-318

Manuscript under review for journal Nat. Hazards Earth Syst. Sci.

Discussion started: 9 October 2017

(c) Author(s) 2017. CC BY 4.0 License.

Dolling KP, Chu P-S, Fujioka F (2005). A climatological study of the Keetch/Byram drought index and fire activity in the Hawaiian Islands. Agricultural and Forest Meteorology 133: $17-27$.

Elhag M, Bahrawi JA (2016). Deliberation of hilly areas for water harvesting application in Western Crete, Greece, Global NEST Journal 18: 621-629.

Fernandes PM, Loureiro C, Guiomar N, Pezzatti GB, Manso FT, Lopes L (2014). The dynamics and drivers of fuel and fire in the Portuguese public forest. Journal of Environmental Management 146: 373-382.

Ganteaume A, Camia A, Jappiot M, San-Miguel-Ayanz J, Long-Fournel M, Lampin C (2013). A review of the main driving factors of forest fire ignition over Europe. Environmental Management 51: 651-662.

Jimenez-Gonzalez MA, De la Rosa JM, Jimenez-Morillo NT, Almendros G, Gonzalez-Perez JA, Knicker H (2016). Post-fire recovery of soil organic matter in a Cambisol from typical Mediterranean forest in Southwestern Spain. Science of the Total Environment 572: 1414-1421.

Keetch JJ, Byram GM (1968). A drought index for forest fire control. Research Paper SE-38. Asheville, NC: US Department of Agriculture, Forest Service, Southeastern Forest Experiment Station. pp. 35.

Lawson BD, Armitage OB (2008). Weather guide for the Canadian Forest Fire Danger Rating System. Natural Resources Canada, Canadian Forest Service, Northern Forestry Centre, Edmonton, Alberta, pp.84. 
Nat. Hazards Earth Syst. Sci. Discuss., https://doi.org/10.5194/nhess-2017-318

Manuscript under review for journal Nat. Hazards Earth Syst. Sci.

Discussion started: 9 October 2017

(c) Author(s) 2017. CC BY 4.0 License.

Leverkus AB, Lorite J, Navarro FB, Sánchez-Cañete EP, Castroa J (2014). Post-fire salvage logging alters species composition and reduces cover, richness, and diversity in Mediterranean plant communities. Journal of Environmental Management 133: 323-331

Levin N, Tessler N, Smith A, McAlpine C (2016). The Human and Physical Determinants of Wildfires and Burnt Areas in Israel. Environmental Management 58: 549-562.

Murray BD, Holmes SA, Webster CR, Witt JC (2012). Post-disturbance plant community dynamics following a rare natural-origin fire in a Tsuga canadensis forest. PLoS One 7: e43867.

Parr CL, Andersen AN, Chastagnol C, Duffaud C (2007). Savanna fires increase rates and distances of seed dispersal by ants. Oecologia 151: 33-41.

Pasqualini V, Oberti P, Vigetta S, Riffard O, Panaiotis C, Cannac M, Ferrat L (2011). A GISbased multicriteria evaluation for aiding risk management Pinus pinaster Ait. forests: a case study in Corsican Island, western Mediterranean Region. Environmental Management 48: 38-56.

Pereira P, Ubeda X, Martin D, Mataix-Solera J, Guerrero C (2011). Effects of a low severity prescribed fire on water-soluble elements in ash from a cork oak (Quercus suber) forest located in the northeast of the Iberian Peninsula. Environmental Research 111: 237-247.

Petropoulos GP, Vadrevu KP, Xanthopoulos G, Karantounias G, Scholze M (2010). A comparison of Spectral Angle Mapper and Artificial Neural Network classifiers combined with Landsat TM imagery analysis for obtaining burnt area mapping. Sensors (Basel) 10: 1967-1985.

Taylor SW, Alexander ME (2006). Science, technology, and human factors in fire danger rating: the Canadian experience. International Journal of Wildland Fire 15:121-135. 
Nat. Hazards Earth Syst. Sci. Discuss., https://doi.org/10.5194/nhess-2017-318

Manuscript under review for journal Nat. Hazards Earth Syst. Sci.

Discussion started: 9 October 2017

(c) Author(s) 2017. CC BY 4.0 License.

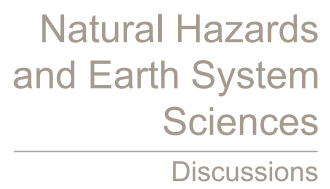

(c) (1)

471 Turco M, Bedia J, Di Liberto F, Fiorucci P, von Hardenberg J, Koutsias N, Llasat MC, Xystrakis

472

F, Provenzale A (2016). Decreasing Fires in Mediterranean Europe. PLoS One 11:

473 e0150663.

474 Van Wagner CE (1970). New developments in forest fire danger rating. Government of Canada,

475 Department of Fisheries and Forestry, Petawawa Forest Experiment Station, Chalk River, Ontario. Information Report PS-X-19. 6 p.

477

Wang Xianli, Wotton BM,. Cantin AS, Parisien M-A, Anderson K, Moore B, Flannigan MD

478 (2017). cffdrs: an R package for the Canadian Forest Fire Danger Rating System. Ecological Processes 6:5

480

Wrathall JE (1985). The hazard of forest fires in southern France. Disasters 9: 104-14.

481

482

483

484

485

486

487

488

489

490

491 
Nat. Hazards Earth Syst. Sci. Discuss., https://doi.org/10.5194/nhess-2017-318

Manuscript under review for journal Nat. Hazards Earth Syst. Sci.

Discussion started: 9 October 2017

(C) Author(s) 2017. CC BY 4.0 License.

(c) (i)

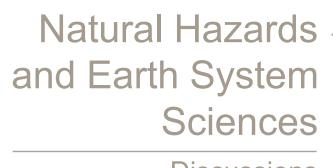

Discussions
492

493

494

495

496

497

498

499

500

501

502

List of Tables

Table 1. Percentage occurrence of FWI values within fire danger class intervals for 2008/2009.

\begin{tabular}{lcccccccccc}
\hline $\begin{array}{l}\text { FWI Limits } \\
\text { Danger class }\end{array}$ & $\begin{array}{c}\mathbf{0 - 1} \\
\text { Very Low }\end{array}$ & \multicolumn{2}{c}{$\begin{array}{c}\mathbf{2 - 5} \\
\text { Low }\end{array}$} & \multicolumn{3}{c}{$\begin{array}{c}\mathbf{6 - 1 2} \\
\text { Moderate }\end{array}$} & \multicolumn{2}{c}{$\begin{array}{c}\text { 13-24 } \\
\text { High }\end{array}$} & \multicolumn{2}{c}{$\begin{array}{c}\text { 24 } \\
\text { Extreme }\end{array}$} \\
\cline { 2 - 11 } & $\mathbf{2 0 0 8}$ & $\mathbf{2 0 0 9}$ & $\mathbf{2 0 0 8}$ & $\mathbf{2 0 0 9}$ & $\mathbf{2 0 0 8}$ & $\mathbf{2 0 0 9}$ & $\mathbf{2 0 0 8}$ & $\mathbf{2 0 0 9}$ & $\mathbf{2 0 0 8}$ & $\mathbf{2 0 0 9}$ \\
March & 25.8 & 29.03 & 51.6 & 29.03 & 16.1 & 25.8 & 6.45 & 16.1 & 0 & 0 \\
April & 3.3 & 16.66 & 13.3 & 3.33 & 50 & 23.33 & 30 & 33.33 & 3.3 & 23.33 \\
May & 0 & 0 & 0 & 3.22 & 38.7 & 0 & 39.03 & 6.45 & 32.25 & 90.32 \\
June & 0 & 0 & 0 & 0 & 0 & 6.66 & 10 & 0 & 90 & 93.33 \\
July & 0 & 0 & 0 & 0 & 0 & 0 & 3.2 & 0 & 96.8 & 100 \\
August & 0 & 0 & 0 & 0 & 0 & 0 & 3.2 & 0 & 96.8 & 100 \\
September & 0 & 0 & 0 & 0 & 0 & 10 & 13.330 & 0 & 86.66 & 90 \\
October & 19.35 & 3.22 & 16.12 & 0 & 32.25 & 9.67 & 19.35 & 22.58 & 12.9 & 64.51 \\
November & 23.33 & 13.33 & 16.66 & 10 & 40 & 13.33 & 16.66 & 20 & 3.3 & 43.33 \\
\hline
\end{tabular}

Table 2. Regression equations for estimating plant moisture content (x) from the KBDI (y).

\begin{tabular}{llcc}
\hline Species & Equation & Regression Coefficient $\left(\mathbf{R}^{2}\right)$ & Variance explained $\mathbb{}$ \\
\hline Piplatherum miliaceum & $\mathrm{y}=904.23-1.881 * \mathrm{x}$ & -0.93 & 0.88 \\
Avena sterrilis & $\mathrm{y}=918.67-7.961 * \mathrm{x}$ & -0.85 & 0.72 \\
Parietaria diffusa & $\mathrm{y}=925.73-7.549 * \mathrm{x}$ & -0.82 & 0.68 \\
Pinus halepensis & $\mathrm{y}=511.78-1.934 * \mathrm{x}$ & 0.20 & 0.04 \\
\hline
\end{tabular}


Nat. Hazards Earth Syst. Sci. Discuss., https://doi.org/10.5194/nhess-2017-318

Manuscript under review for journal Nat. Hazards Earth Syst. Sci.

Discussion started: 9 October 2017

(c) Author(s) 2017. CC BY 4.0 License.
Natural Hazards and Earth System

Sciences

Discussions

(c) (i)

505

506

507

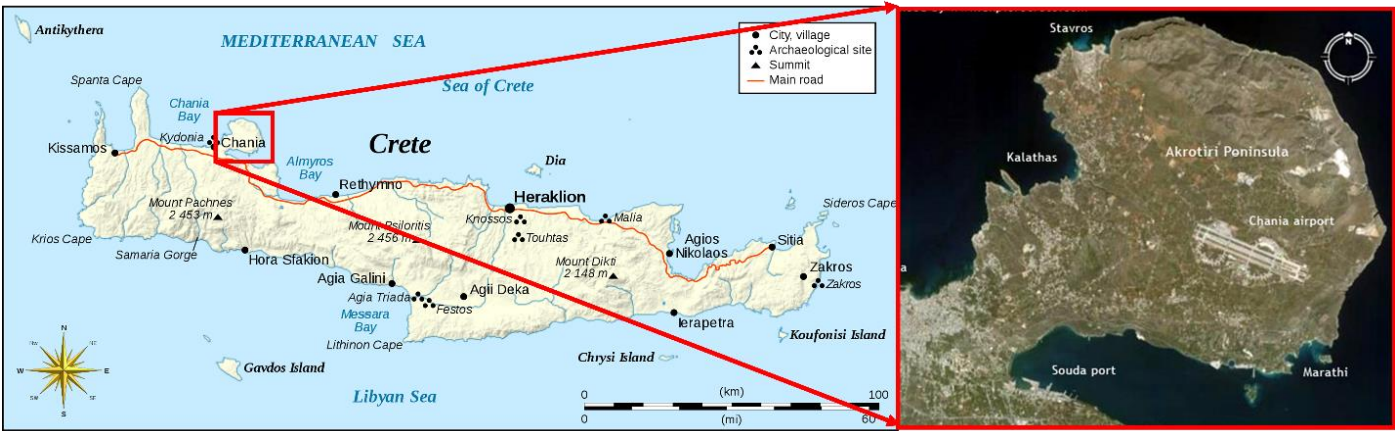

Figure 1. Location of the study area.

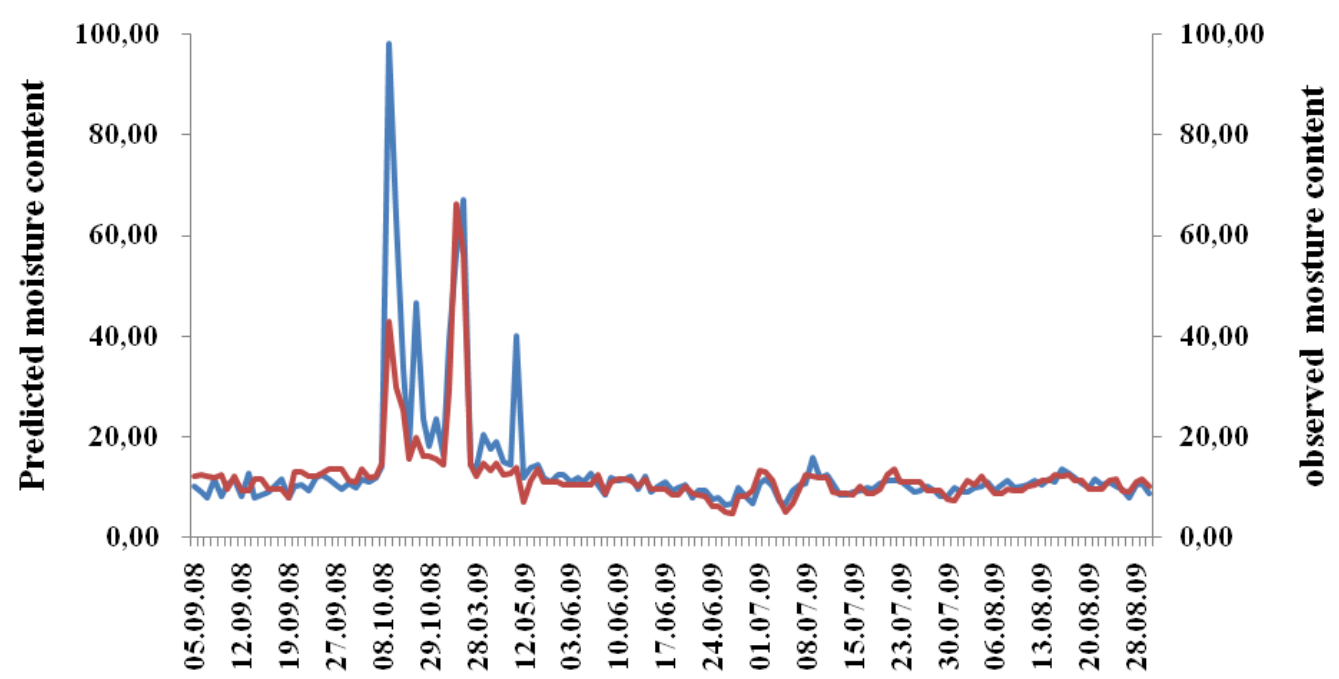

Date

Figure 2. Comparison of observed (red) and predicted (blue) fine fuel moisture content values obtained from the (FWI) in Days. 
Nat. Hazards Earth Syst. Sci. Discuss., https://doi.org/10.5194/nhess-2017-318

Manuscript under review for journal Nat. Hazards Earth Syst. Sci.

Discussion started: 9 October 2017

(c) Author(s) 2017. CC BY 4.0 License.

(c) (i)
Natural Hazards and Earth System

Sciences

Discussions

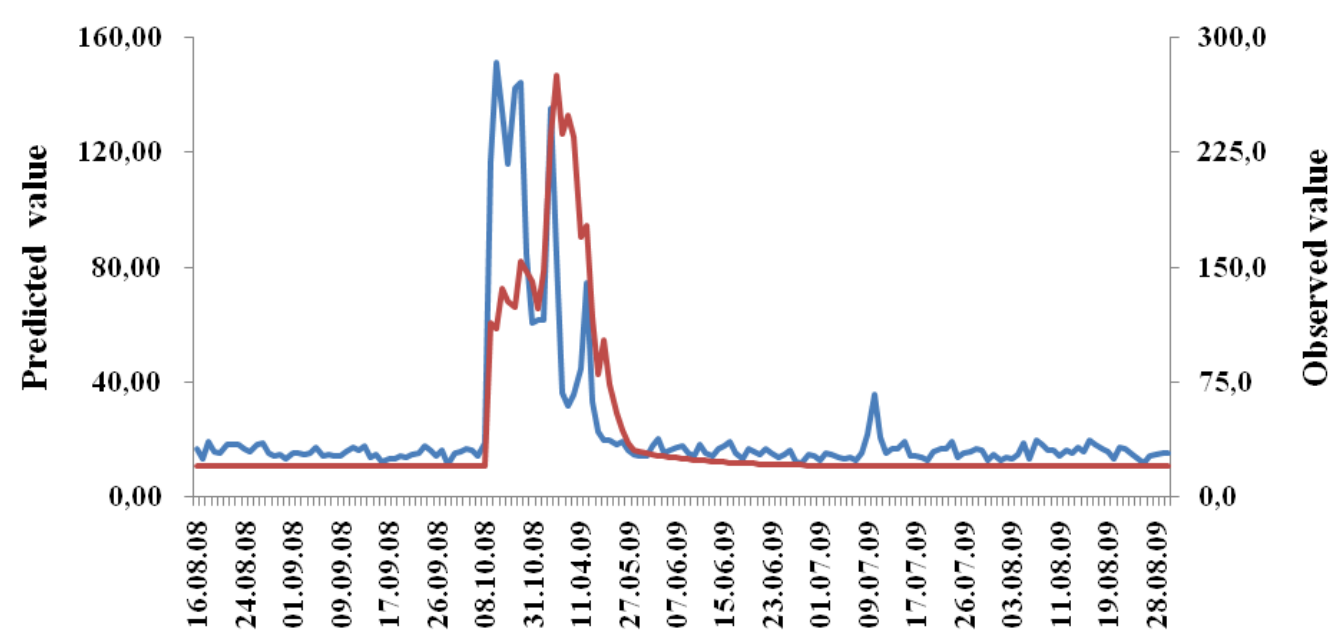

510

Date

511 Figure 3. Comparison of observed (red) and predicted (blue) duff moisture content values

512 obtained from the (FWI) in Days.

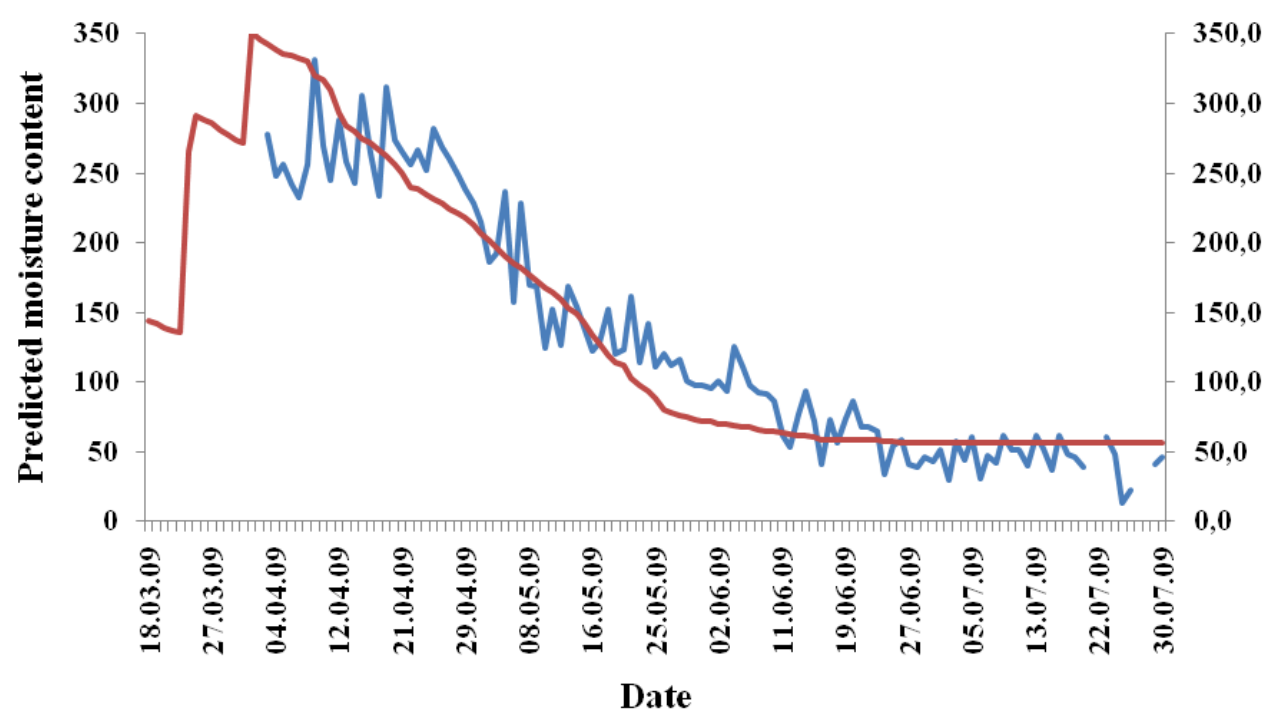

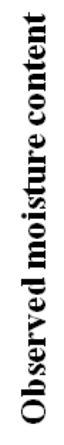

Figure 4. Comparison charts of observed (dots) and predicted (line) moisture content of 
Nat. Hazards Earth Syst. Sci. Discuss., https://doi.org/10.5194/nhess-2017-318

Manuscript under review for journal Nat. Hazards Earth Syst. Sci.

Discussion started: 9 October 2017

(c) Author(s) 2017. CC BY 4.0 License.
Natural Hazards and Earth System

Sciences

Discussions

(c) $\underset{0}{(1)}$

516

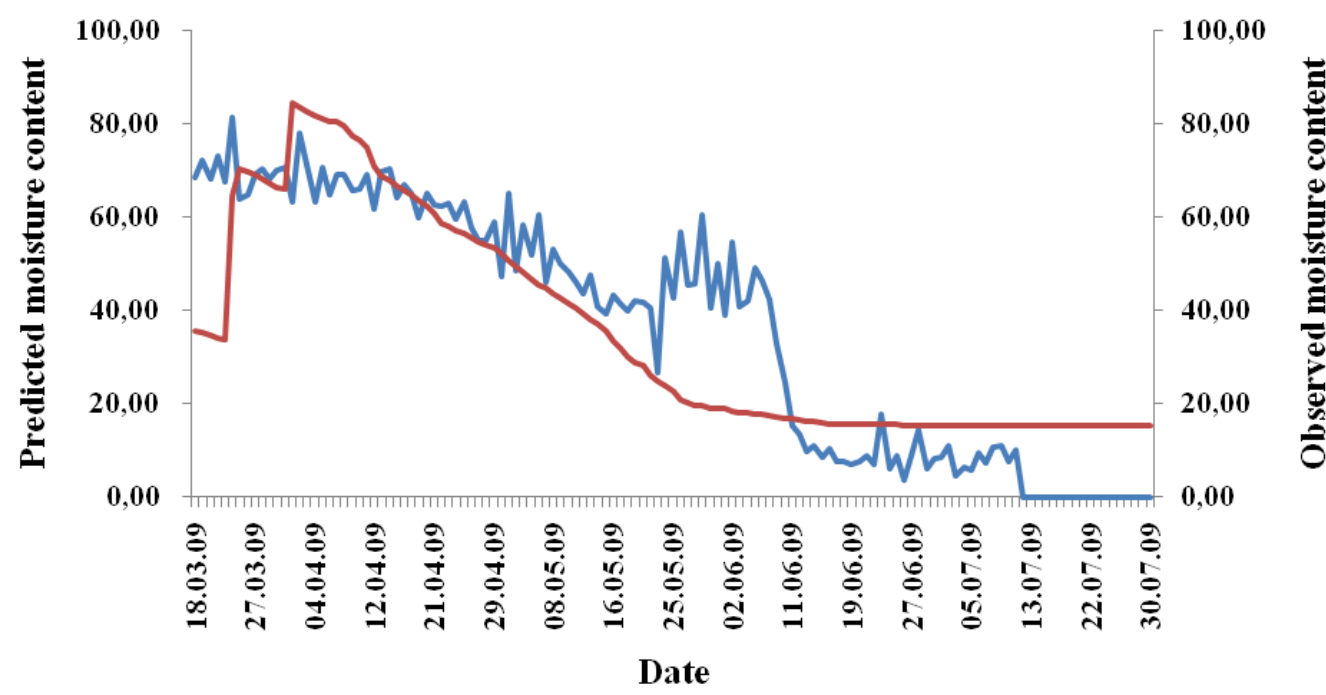

517

518

Figure 5. Comparison charts of observed (Dots) and predicted (line) moisture content of Parietaria diffusa by the KBDI

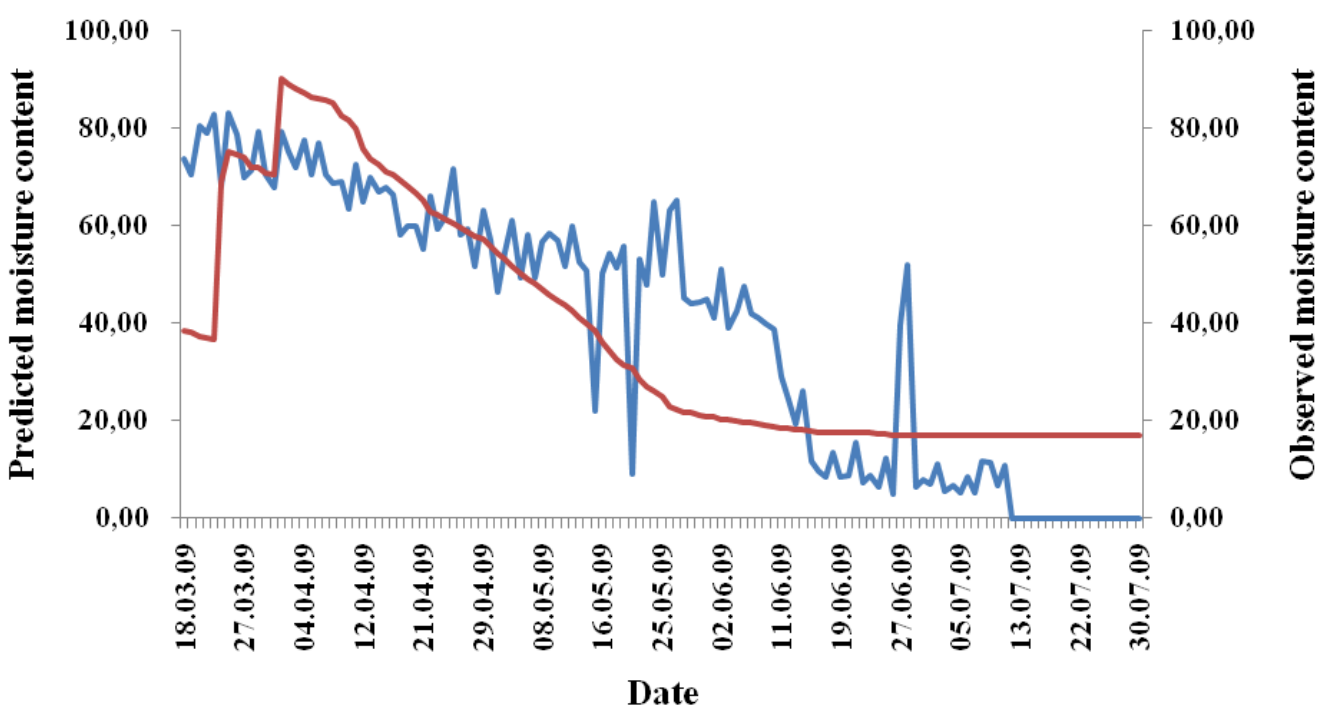

Figure 6. Comparison charts of observed (Dots) and predicted (line) moisture content of 